\title{
The Impact of Hepatic Arterial Variations and Reconstructions on Arterial Complications in Liver Transplantation
}

\author{
Catalina Nausica PICU ${ }^{1,2}$, Florin BOTEA ${ }^{1,2}$, Vladislav BRASOVEANU ${ }^{1,2}$, Doina HREHORET1, \\ Sorin ALEXANDRESCU', Razvan GRIGORIE', Irinel POPESCU ${ }^{1,2}$
}

\begin{abstract}
Background: The purposes of the study were to determine the variations in hepatic arterial supply, to delineate the optimal methods of arterial anastomoses and reconstructions in liver transplantation and to analyse the incidence of arterial complications. Methods: The surgical anatomy of the extrahepatic arterial vascularization was investigated retrospectively in 209 donors and patients who underwent liver transplantation at Fundeni Clinical Institute (Bucharest, Romania) from January 1, 2015 to December 31, 2017. The vascular anatomy of the hepatic grafts was classified according to Michels' description and other rare variations. Results: Anatomical variants of the classical pattern were detected in $26.3 \%$ of the livers $(n=55)$. The most common variant was a replaced right hepatic artery arising from the superior mesenteric artery $(n=17 ; 8.13 \%)$, followed by a common hepatic artery from superior mesenteric artery $(n=6 ; 2.87 \%)$. Arterial reconstructions were reported in 97 cases $(45.5 \%)$. In recipients, used sites were intermediate: common hepatic artery $(\mathrm{CHA})$ in $73.8 \%(\mathrm{n}=158)$, distal: proper hepatic artery $(\mathrm{PHA})$ or common hepatic artery/gastro-duodenal artery bifurcation (CHA/GDA bifurcation) in 16.4\% $(n=35)$ and proximal: coeliac trunk-splenic artery-aorta $(C T-S A-A)$ in $9.3 \%(n=20)$ of patients. Most common reconstructions were short graft artery $(\mathrm{CT})$ on the recipient $\mathrm{CHA}(\mathrm{n}=33,34.02 \%)$ and long graft artery: complex reconstruction between $\mathrm{CT}$ and superior mesenteric artery (SMA) - accessory right hepatic artery (RHA) from SMA on CHA $(n=12,12.37 \%)$ and right hepatic graft artery on PHA or CHA/GDA bifurcation ( $n=16,16.49 \%)$. Conclusion: The information about the different hepatic arterial patterns, as well as establishing specific methods for arterial anastomoses and reconstructions is important in the determination of better outcomes.
\end{abstract}

Keywords: hepatic arterial anatomy, hepatic arterial variations, arterial reconstructions, liver transplantation, hepatic artery thrombosis.

\section{Rezumat}

Context: Scopurile studiului au fost determinarea variațiilor arteriale hepatice, descrierea metodelor optime de anastomoze și reconstructii arteriale în transplantul hepatic și analizarea incidentei complicatiilor arteriale. Metode: Anatomia chírurgicală a vascularizației arteriale hepatice a fost investigată retrospectiv la 209 donatori și pacienți transplantați hepatic în Institutul Clinic Fundeni (București, România), în perioada 1 ianuarie 2015-31 decembrie 2017. Anatomia vasculară hepatică a fost clasificată conform celei descrise de Michel și în plus alte anomalii rare. Rezultate: Variante anatomice au fost detectate în $26,3 \%$ din cazuri $(n=55)$. Cea mai comună variantă a fost artera hepatică dreaptă înlocuită din artera mezenterică superioară $(n=17 ; 8,13 \%)$, urmată de artera hepatică comună din artera mezenterică superioară $(n=6 ; 2,87 \%)$. Reconstrucții arteriale au fost raportate în 97 de cazuri $(45,5 \%)$. La primitori siteurile folosite au fost intermediare: artera hepatică comună (AHC) în 73,8\% (n = 158), distale: artera hepatică proprie (AHP) sau artera hepatică comună la bifurcația arterei gastro-duodenale (AHC/AGD) în 16,4\% din

${ }^{1}$ "Dan Setlacec" Center of General Surgery and Liver Transplantation, Fundeni Clinical Institute, Bucharest, Romania

2 "Titu Maiorescu" University of Medicine, Bucharest, Romania
Corresponding author:

Catalina Nausica PICU, „Titu Maiorescu" University of Medicine, Bucharest, Romania.

E-mail: nausica_picu@yahoo.com 
cazuri $(n=35)$ sau proximale: trunchi celiac - artera splenică - aorta (TC-AS-A) în 9,3\% din pacienți $(n=20)$. Cele mai frecvente reconstrucții au fost anastomoza arterială între artera scurtă a grefonului (TC) și AHC a primitorului (n = 33; 34,02\%) și artera lungă a grefonului: reconstrucție complexă între TC și artera mezenterică superioară (AMS) artera hepatică dreaptă accesorie din AMS cu AHC ( $n=12 ; 12,37 \%)$ și artera hepatică dreaptă a grefonului cu AHP sau AHC la bifurcația AGD ( $n=16 ; 16,49 \%)$. Concluzie: Informațiile despre diferite variante arteriale hepatice, precum și stabilirea metodelor specifice pentru anastomoze arteriale și reconstrucții este importantă în determinarea unor rezultate mai bune.

Cuvinte cheie: anatomie arterială hepatică, variații arteriale hepatice, reconstrucții arteriale, transplant hepatic, tromboză arterială hepatică.

\section{INTRODUCTION}

Knowledge of hepatic arterial vascularization has a significant relevance for the daily practice. The patterns of hepatic arterial supply are not constant. The usual anatomy of the hepatic arterial vascularization is a common hepatic artery arising from the celiac axis, accounting for 25 to $75 \%$ of the cases. In the variant patterns, the hepatic lobes receive arterial flow through branches coming from the superior mesenteric artery (SMA), left gastric artery (LGA) or, rarely, from other arterial trunks. Since Michels published his first report, several studies have reported not only common and rare hepatic artery variants, but also different classifications ${ }^{1}$.

Hepatic artery thrombosis (HAT) after liver transplantation is a severe complication often requiring urgent retransplantation. Patients with HAT may present with a fulminant clinical course or a subtle and indolent course. The time of onset of HAT has been correlated with the severity of subsequent complications, with late HAT thought to have a more benign course. However, outcomes still vary considerably ${ }^{2,3}$.

The main purpose of this study is to accurately describe the anatomic hepatic artery in 209 donors and patients who underwent liver transplantation at Fundeni Clinical Institute (Bucharest, Romania), to delineate the optimal methods of arterial anastomoses and reconstructions in liver transplantation and to analyse the incidence of arterial complications. Indeed, we believe that surgical anatomy descriptions have a greater value for surgeons than studies based on radiologic images or autopsy findings.

\section{MATERIALS AND METHODS}

We analysed a retrospectively database of 209 patients who underwent liver transplantation at Fundeni Clinical Institute (Bucharest, Romania) from January 1,
2015 to December 31, 2017. Monitoring was carried out until April 2019 with a median follow-up of 34 months (range: $16-52$ months). Liver grafts were from deceased donors $(n=187)$ or living donors $(n=22) \cdot \mathrm{Pa}-$ tients under the age of 18, patients with liver transplantation (LT) before the study period and retransplantation during the study period as well as patients with missing data were excluded. The main criterion considered as complication was HAT (early - occurring within 1-month post-LT or late - occurring after 1 month post-LT), defined as a lack of arterial flow determined by Doppler ultrasound and confirmed by a computed tomography scan (CT scan). Preoperative evaluation, surgical data, postoperative complications and 90-day mortality were recorded.

After a preoperative visit including a CT scan, all cases were discussed in the multidisciplinary transplantation meeting to assess the vascular anatomy of the recipient and discuss technical options. As recommended, the patency and size of the hepatic artery (HA) as well as the identification of any variation that could result in reduced flow of the HA were systematically analyzed with a radiologist.

All liver transplantations were performed using a surgical technique under this sequence: (1) a piggyback caval anastomosis (three-vein technique), (2) an endto-end portal anastomosis, (3) an arterial anastomosis and (4) a duct-to-duct biliary anastomosis. No porto-caval shunt was used. A sequential revascularization was done, and the graft was first perfused via the portal vein and then via the hepatic artery. In the absence of any hemorrhagic complications and/or low platelet count, all patients received prophylactic low molecular weight heparin. Acetylsalicylic acid was reserved for small arteries (diameter $<5 \mathrm{~mm}$ ) and/ or complex arterial reconstructions.

Postoperative arterial patency was examined by Doppler ultrasound every day during the first week 
routinely. Subsequent examinations were carried out as indicated clinically.

The arterial reconstruction was planned before the transplantation to reduce prolonged warm ischemia time (number, size and quality of the donor and recipient arteries). In case of inadequate HA flow (small hepatic artery, intraoperative intimal dissection, mass ligation of hepatic pedicles in patients with portal cavernoma), dissection of the common hepatic artery (CHA) and then of the recipient celiac trunk (CT) was performed to determine the future site of arterial anastomosis. On a case-by-case basis, an adapted and oriented arterial anastomosis with intima-to-intima opposition was fashioned under a surgical loop with a running or separated $6-0,7-0$ or $8-0$ polypropylene suture.

\section{STATISTICAL ANALYSIS}

Variables were compared between patients with and without arterial complications with Fisher's exact test, Student t test or Mann-Whitney test, as appropriate. Odds Ratio (OR 95\%CI) effect size was estimated by the logistic regression model and all variables with $\mathrm{p}<0.20$ in univariate analysis were included in the multivariate analysis with Wald's backward selection method. In order to account for the different lengths of follow-up in the cohort, survival curves were estimated with the Kaplan-Meier method and compared with Log-rank tests. Hazard Ratio (HR 95\%CI) was estimated by the Cox regression model. The follow-up was decided as the number of months between the surgery and the last follow-up or the date of death. Statistical analyses were performed using IBM SPSS Statistics version 26.0 for Windows and IBM SPSS Statistics version 27 for MacOS. A p value < 0.05 was considered statistically significant.

\section{RESULTS}

\section{Demographic and operative data}

During the study period, 209 patients with primary liver transplantation involving whole organ graft or LDLT were included. Men were detected in $61.4 \%$ of the non HAT/HAS (hepatic artery thrombosis/ hepatic artery stenosis) group and in $85.5 \%$ of the HAT/ HAS group. The patients of the HAT/HAS group were 8 years younger than the non HAT/HAS group. All the patients presented a Child-Pugh score C. No difference was found concerning recipient age, gender, MELD (Model for End-Stage Liver Disease) score, HCC (hepatocellular carcinoma) as a cause of liver disease, erythrocyte transfusions and major complications $(p>0.05)$. Arterial variations and arterial reconstructions were also not significantly associated with HAT/ HAS ( $p=0.373$ and respectively $p=0.703$ ). The HAT/ HAS group had longer operative time than the non HAT/HAS group ( $\mathrm{p}=0.007)$.

Table 1. Recipient characteristics: Comparison of the HAT/HAS and non-HAT/HAS groups

\begin{tabular}{|c|c|c|c|}
\hline \multirow[t]{2}{*}{ Recipient characteristics } & $\begin{array}{l}\text { non HAT/ } \\
\text { HAS }\end{array}$ & HAT/HAS & \multirow{2}{*}{$\begin{array}{c}p \\
\text { value }\end{array}$} \\
\hline & $(n=202)$ & $(n=7)$ & \\
\hline Age* & $\begin{array}{l}50.5+- \\
11.25 \\
\end{array}$ & $42.0+-16.5$ & 0.053 \\
\hline Gender M & $124(61.4 \%)$ & $6(85.7 \%)$ & 0.258 \\
\hline $\mathrm{HCC}$ & $55(27.1 \%)$ & $1(14.3 \%)$ & 0.677 \\
\hline Child score & $\mathrm{C}$ & $\mathrm{C}$ & - \\
\hline MELD score** & $18(6-35)$ & $16(10-21)$ & 0.566 \\
\hline Operative time (hours)** & $\begin{array}{l}6.3(4- \\
13.2) \\
\end{array}$ & $\begin{array}{l}8.7(5.6- \\
10.3) \\
\end{array}$ & 0.007 \\
\hline Blood products $(U) * *$ & $2(0-32)$ & $2(0-9)$ & 0.783 \\
\hline Arterial anatomy anomalies & $50(24.8 \%)$ & $3(42.9 \%)$ & 0.373 \\
\hline Arterial reconstructions & $90(44.6 \%)$ & $4(57.1 \%)$ & 0.703 \\
\hline Major complications*** & $50(24.8 \%)$ & $4(57.1 \%)$ & 0.075 \\
\hline Aortic conduit & $5(2.5 \%)$ & $0(0.0 \%)$ & 1.000 \\
\hline Vascular graft & $6(3.0 \%)$ & $0(0.0 \%)$ & 1.000 \\
\hline Aortic patch & $7(3.5 \%)$ & $0(0.0 \%)$ & 1.000 \\
\hline Short graft artery & $31(15.3 \%)$ & $2(28.6 \%)$ & 0.305 \\
\hline Long graft artery & $10(5.0 \%)$ & $2(28.6 \%)$ & 0.054 \\
\hline Median follow-up (months) & $35(0-52)$ & $23(0-51)$ & 0.656 \\
\hline 90-day mortality & $26(12.9 \%)$ & $2(28.6 \%)$ & 0.238 \\
\hline
\end{tabular}

* The data are presented as medians, standard deviations.

$* *$ The data are presented as medians and ranges.

***Major complications - including grade Clavien Dindo IIIA, IIIB, IV, V.

The protective effect of the age was the same in univariate and multivariate analysis $(\mathrm{p}=0.064$ and $\mathrm{p}=0.118$ ). Major complications increased 4 times (95\%CI: 0.8819.73) the odds of HAT/HAS in univariate analysis and 3.2 times (95\%CI: $0.58-17.76)$ in multivariate analysis, without statistical significance $(\mathrm{p}=0.073$ and $\mathrm{p}=0.179$ ). Long gaft artery increases 9.6 and 5.5 times the odds of HAT/HAS in univariate and multivariate analysis ( $p=0.017$ and 0.072 ). Each operative hour significantly increases $(69 \%)$ the odds of HAT/HAS $(\mathrm{OR}=1.69 ; 95 \% \mathrm{CI}: 1.16-2.49 ; \mathrm{p}=0.007)$, being also 
statistically significant in the multivariate analysis $(\mathrm{OR}=1.63$; 95\%CI: 1.12-2.43; $\mathrm{p}=0.016)$.

Table 2. Uni and multivariate ccomparison of the HAT/HAS and nonHAT/HAS groups

\begin{tabular}{|l|c|c|c|c|}
\hline \multirow{2}{*}{$\begin{array}{l}\text { Recipient } \\
\text { characteristics }\end{array}$} & \multicolumn{2}{|c|}{ Univariate } & \multicolumn{2}{c|}{ Multivariate } \\
\cline { 2 - 5 } & OR (Cl95\%) & $\begin{array}{c}\text { p } \\
\text { value }\end{array}$ & OR (Cl95\%) & $\begin{array}{c}\text { p } \\
\text { value }\end{array}$ \\
\hline Age & $0.95(0.89-1.00)$ & 0.064 & $0.95(0.89-1.01)$ & 0.118 \\
\hline $\begin{array}{l}\text { Long graft } \\
\text { artery }\end{array}$ & $9.58(1.46-50.4)$ & 0.017 & $5.48(0.86-34.98)$ & 0.072 \\
\hline $\begin{array}{l}\text { Operative time } \\
\text { (hours) }\end{array}$ & $1.69(1.16-2.49)$ & 0.007 & $1.63(1.10-2.43)$ & 0.016 \\
\hline $\begin{array}{l}\text { Major } \\
\text { complications }\end{array}$ & $4.05(0.88-19.73)$ & 0.073 & $3.22(0.58-17.76)$ & 0.179 \\
\hline
\end{tabular}

Prominent liver transplant indications (table 3) were: (1) hepatocellular carcinoma in 56 patients $(26.79 \%)$, (2) viral cirrhosis $\mathrm{B}+\mathrm{D}$ in 48 patients $(22.96 \%)$, (3) viral cirrhosis $\mathrm{C}$ in 29 patients (13.87\%), (4) alcoholic liver disease in 28 patients (13.39\%).

Table 3. Transplant indications for the HAT/HAS and nonHAT/HAS groups

\begin{tabular}{|l|c|c|}
\hline Indications & $\begin{array}{c}\text { non HAT/HAS } \\
\text { group }(\mathbf{n}=\mathbf{2 0 2})\end{array}$ & $\begin{array}{c}\text { HAT/HAS } \\
\text { group }(\mathbf{n}=\mathbf{7})\end{array}$ \\
\hline Hepatocellular carcinoma & 55 & 1 \\
\hline Viral cirrhosis B+D & 46 & 2 \\
\hline Viral cirrhosis C & 28 & 1 \\
\hline Alcoholic liver disease & 28 & 0 \\
\hline Acute liver failure & 6 & 0 \\
\hline Budd-Chiari syndrome & 6 & 0 \\
\hline Primary sclerosing cholangitis & 4 & 0 \\
\hline Primary biliary cirrhosis & 2 & 1 \\
\hline Other indications & 27 & 2 \\
\hline
\end{tabular}

\section{ARTERIAL ANATOMY AND TYPES OF RECONSTRUCTIONS}

Liver arterial anatomy was classic (Type I) in 154 patients $(73.7 \%)$. We found arterial variations (donors and recipients) in 55 patients (26.3\%): a replaced LHA (left hepatic artery; Type II) in 5 patients (2.39\%), a replaced RHA (right hepatic artery; Type III) in 17 patients $(8.13 \%)$, replaced left and right arteries (Type IV) in 3 patients (1.43\%), accessory LHA from LGA (type $\mathrm{V}$ ) in 5 patients (2.39\%), an accessory RHA from SMA (type VI) in 4 patients (1.91\%), accessory RHA and LHA (type VII) in 4 patients (1.91\%), an accessory RHA or LHA and a replaced LHA or RHA (type VIII) in 3 patients (1.43\%) and a CHA from SMA (Type IX) in 6 patients (2.87\%), CHA separate origin from aorta (type $\mathrm{X}$ ) in 1 patient $(0.48 \%)$. There were also observed rare arterial anomalies (7 cases $-3.35 \%)$ : artery for segment IV from RHA, 2 LHA from proper HA, artery for segments V-VI from GDA, CA-SMA common trunk (celiac-mesenteric trunk), early bifurcation of the HA, LHA from CA + RHA from aorta, RHA from CA.

Arterial reconstructions were reported in 97 cases (45.5\%). In recipients, used sites were intermediate $(\mathrm{CHA})$ in $73.8 \%(\mathrm{n}=158)$, distal $(\mathrm{PHA}$ or $\mathrm{CHA} /$ GDA bifurcation) in $16.4 \%(\mathrm{n}=35)$ and proximal $(\mathrm{CT}-\mathrm{SA}-\mathrm{A})$ in $9.3 \%(\mathrm{n}=20)$ of patients. The most common reconstructions were short graft artery $(\mathrm{CT})$ on the recipient $\mathrm{CHA}(\mathrm{n}=33,34.02 \%)$ and long graft artery (complex reconstruction between TC and SMA - accessory RHA from SMA) on CHA ( $\mathrm{n}=$ $12,12.37 \%$ ) and right hepatic graft artery on PHA or CHA/GDA bifurcation ( $\mathrm{n}=16,16.49 \%)$. A donor iliac artery interposition graft was used in 6 cases (8.8\%), when adequate inflow from the native hepatic artery cannot be ensured, as in very small vessels or highgrade celiac axis stenosis. Recipient aorta was used in 5 cases (7.1\%). A Carrel aortic patch was performed in 7 cases $(10.3 \%)$.

Arterial anatomy variations are detailed in Table 4. 
Table 4. Arterial anatomy variations

\begin{tabular}{|c|c|c|c|}
\hline Description & $\begin{array}{c}\text { Type } \\
\text { (Michels and } \\
\text { Hiatt) }\end{array}$ & $\begin{array}{l}\text { Number } \\
\text { of cases }\end{array}$ & $\%$ \\
\hline standard anatomy & 1 & 154 & 73.7 \\
\hline replaced LHA & II & 5 & 2.39 \\
\hline replaced RHA & III & 17 & 8.13 \\
\hline replaced RHA and LHA & IV & 3 & 1.43 \\
\hline accessory LHA from LGA & $\mathrm{V}$ & 5 & 2.39 \\
\hline accessory RHA from SMA & VI & 4 & 1.91 \\
\hline accessory RHA and LHA & VII & 4 & 1.91 \\
\hline $\begin{array}{l}\text { accessory RHA and LHA and } \\
\text { replaced LHA or RHA }\end{array}$ & VIII & 3 & 1.43 \\
\hline $\mathrm{CHA}$ replaced to SMA & IX & 6 & 2.87 \\
\hline CHA separate origin from aorta & $x$ & 1 & 0.48 \\
\hline $\begin{array}{l}\text { Rare anomalies: } \\
\text { - artery for segment IV from } \\
\text { RHA } \\
\text { - } 2 \text { LHA from proper HA } \\
\text { - artery for segments } \mathrm{V} \text {-VI from } \\
\text { GDA } \\
\text { - CA-SMA common trunk } \\
\text { (celiac-mesenteric trunk) } \\
\text { - early bifurcation of the HA } \\
\text { - LHA from CA + RHA from } \\
\text { aorta } \\
\text { - RHA from CA }\end{array}$ & & 7 & 3.35 \\
\hline Total cases & & 209 & \\
\hline
\end{tabular}

Prominent arterial reconstructions are described in Table 5.

Table 5. Prominent arterial reconstructions

\begin{tabular}{|l|l|l|}
\hline Prominent arterial reconstructions & Cases & $\%$ \\
\hline Short graft artery (CT) - recipient CHA & 33 & 34.02 \\
\hline $\begin{array}{l}\text { Long graft artery (complex reconstruction } \\
\text { between TC and SMA; accessory RHA from } \\
\text { SMA) - recipient CHA }\end{array}$ & 12 & 12.37 \\
\hline $\begin{array}{l}\text { Right hepatic graft artery - PHA or CHA/GDA } \\
\text { bifurcation }\end{array}$ & 16 & 16.49 \\
\hline Donor iliac artery interposition graft & 6 & 8.8 \\
\hline Recipient aorta & 5 & 7.1 \\
\hline Carrel aortic patch & 7 & 10.3 \\
\hline
\end{tabular}

\section{INCIDENCE AND PRESENTATION OF ARTERIAL COMPLICATIONS}

Early HAT was diagnosed in 3 patients (1.43\%) of the 209 patients with LT with a median delay of 8 days after LT (range: 5-15). Late HAT occurred in 2 patients $(0.95 \%)$ with a median delay of 80 days (range: $40-120)$. There were described 2 cases of hepatic artery anastomotic stenosis of the 209 patients with LT. Presentation of the arterial complications included elevated transaminases, biliary complications (biliary leakage), fever, abnormal results on Doppler images (abnormal RI), sepsis and graft dysfunction or failure.

\section{MANAGEMENT OF HAT, OUTCOMES AND SURVIVAL ANALYSIS}

Of the 7 patients with arterial complications, all patients received medical treatment (acetylsalicylic therapy), 4 patients underwent endovascular treatment with Actilyse and thrombectomy and 2 patients underwent retransplantation (at POD 10 and 46).

The mortality of patients with arterial complications was $28.6 \%(\mathrm{n}=2)$, while the mortality of patients without arterial complications was $17.3 \%(n=35)$. Mean survival time in the HAT/HAS group was 43.9 months versus 36.9 months in the nonHAT/HAS group, without statistical significance $(\mathrm{p}=0.365)$. The risk of mortality during the follow-up is increased in the HAT/HAS group: HR=1.91 (95\%IC: $0.46-7.93$ ), compared with the nonHAT/HAS group.

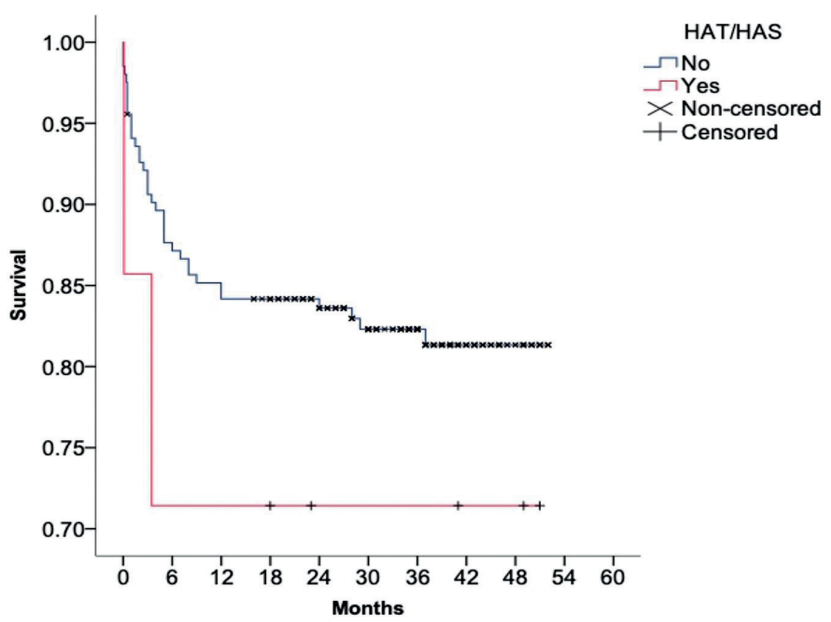

Figure 1. Kaplan-Meier curves - arteral complications for the 2 groups (nonHAT/HAS and HAT/HAS) 
The mortality of patients without arterial anomalies was $19.2 \%(n=30)$, while the mortality of patients with arterial anomalies was $13.2 \%(\mathrm{n}=7)$. Mean survival time in the arterial anomalies group was 45.5 months versus 43.1 in the standard anatomy group, with no significant difference $(\mathrm{p}=0.366)$. Arterial anomalies were a protector factor for mortality during the follow-up (HR: 0.69; 95\%CI:0.30 -1.56).

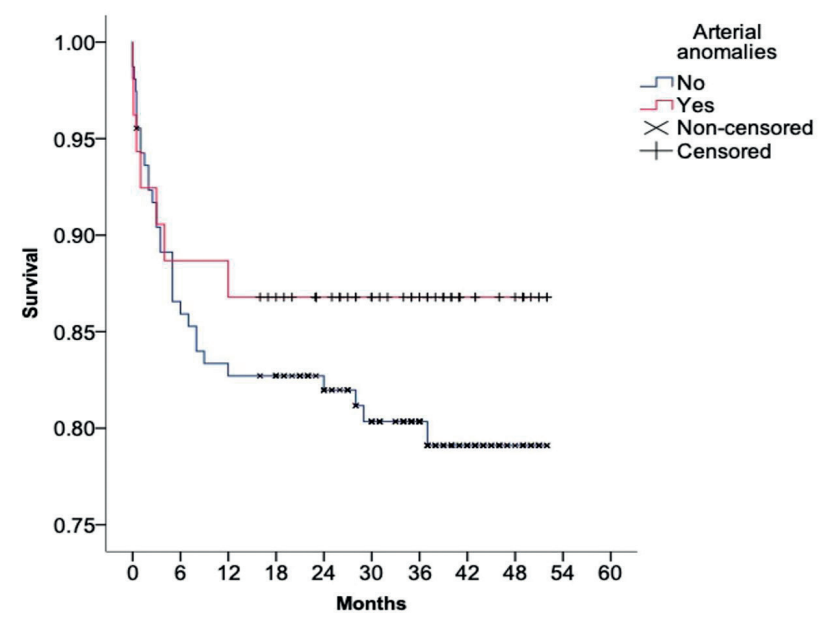

Figure 2. Kaplan-Meier curves - standard anatomy and arterial anomalies

The mortality of patients with standard anastomoses was $22.6 \%$ ( $n=26)$, while the mortality of patients with arterial reconstructions was $11.7 \%(n=11)$. Mean survival time in the arterial reconstructions group was 46.2 months, versus 41.8 in the standard anastomoses group ( $\mathrm{p}=0.069)$. Arterial reconstructions were a protector factor for mortality during the follow-up (HR: 0.53; 95\%CI: 0.26 - 1.07).

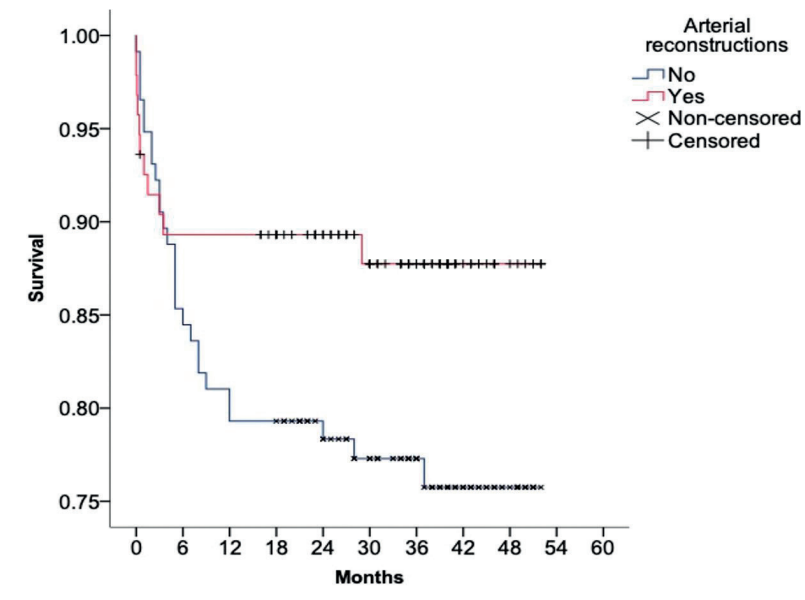

Figure 3. Kaplan-Meier curves - standard anastomoses and arterial reconstructions

\section{DISCUSSION}

Our main findings can be summarized as follows: the prevalence of anatomical variants was $26.3 \%$, a percentage similar to that reported in other series ${ }^{4,5}$; most of the variants described fit into Michels' classification; the most common anatomical variants in our series were a replaced right hepatic artery (type III) in $17 \mathrm{pa}-$ tients (8.13\%), in agreement with previous studies and a CHA from SMA (type IX) in 6 patients (2.87\%). The findings of the present study highlight the fact, already observed in previous studies, that the extrahepatic arterial distribution is variable and that different anatomic variants can occur in a high percentage of cases. These arterial patterns are relevant in the procurement of donor livers and also in the planning and performance of all types of liver transplantations ${ }^{7}$.

We considered it important to identify all the hepatic arteries and to classify them as "accessory" or "replaced". Indeed, replaced arteries must be always preserved; in contrast, accessory arteries do not necessarily need to be reconstructed if there is adequate backflow after the anastomosis of the other branch or if arterial flow in all the segments is demonstrated by intraoperative Doppler ultrasonography ${ }^{6}$.

The analysis of these data shows the predominance of type I (no arterial variations, a single hepatic artery, which originates in the celiac trunk): 154 cases (73.7\%). 10 cases $(4.78 \%)$ had left hepatic artery (replaced or accessory) as left gastric branch, and 21 (10.04\%) had a right hepatic artery (replaced or accessory) originating from the superior mesenteric artery. 6 cases $(2.87 \%)$ presented a single hepatic artery originating from the superior mesenteric. 7 cases were not described in the Hiatt classification. The most common reconstruction was CT on the recipient CHA ( $\mathrm{n}=33,34.02 \%)$ and long graft artery (complex reconstruction between TC and SMA - accessory RHA from SMA) on CHA ( $\mathrm{n}=$ $12,12.37 \%)$ and right hepatic graft artery on PHA or CHA/GDA bifurcation ( $\mathrm{n}=16,16.49 \%)$. A donor iliac artery interposition graft was used in 6 cases (8.8\%), when adequate inflow from the native hepatic artery cannot be ensured, as in very small vessels or highgrade celiac axis stenosis. Recipient aorta was used in 5 cases $(7.1 \%)$. A Carrel aortic patch was performed in 7 cases $(10.3 \%)$.

Arterial variations and arterial reconstructions were not significantly associated with HAT/HAS ( $p=0.373$ 
and respectively $\mathrm{p}=0.703$ ). The HAT/HAS group had longer operative time than the nonHAT/HAS group $(\mathrm{p}=0.007)$. Major complications increased 4 times (95\%CI: 0.88-19.73) the odds of HAT/HAS in univariate analysis and 3.2 times (95\%CI: $0.58-17.76)$ in multivariate analysis, without statistical significance $(\mathrm{p}=0.073$ and $\mathrm{p}=0.179)$. Long gaft artery increases 9.6 times and 5.5 times the odds of HAT/HAS in univariate and multivariate analysis ( $\mathrm{p}=0.017$ and 0.072 ). Each operative hour significantly increases $(69 \%)$ the odds of HAT/HAS (OR=1.69; 95\%CI: 1.16 - 2.49; p=0.007), being also statistically significant in the multivariate analysis $(\mathrm{OR}=1.63$; 95\%CI: $1.12-2.43$; $\mathrm{p}=0.016)$. The mortality of patients with arterial complications was $28.6 \%$ ( $\mathrm{n}=2)$, while the mortality of patients without arterial complications was $17.3 \%(\mathrm{n}=35)$. The risk of mortality during the follow-up is increased in the HAT/HAS group: HR=1.91 (95\%IC: 0.46 - 7.93), compared with the non HAT/HAS group.

While transplantation is the most effective treatment for acute and chronic end-stage liver disease, it is also a procedure with significant morbidity and mortality, particularly in the early postoperative period. This crucial time can encompass several complications, the most significant being primary graft nonfunction and hepatic artery thrombosis ${ }^{8-10}$. Hepatic artery thrombosis is the second main cause of liver graft failure. The consensus for early HAT definition consists of an arterial thrombosis detected during the first month after liver transplantation. HAT is associated with markedly increased morbidity, being the leading cause of graft loss (53\%) and mortality (33\%) during the immediate postoperative period. However, improvements in postoperative care have resulted in a marked reduction of its incidence ${ }^{10,11}$.

Early hepatic artery thrombosis was diagnosed in 3 patients (1.43\%) of the 209 patients with LT, with a median delay of 8 days after LT (range: 5-15). Late hepatic artery thrombosis occurred in 2 patients $(0.95 \%)$ with a median delay of 80 days (range: $40-120$ ). There were described 2 cases of hepatic artery anastomotic stenosis. Of the 7 patients with arterial complications, all patients received medical treatment (acetylsalicylic therapy), 4 patients underwent endovascular treatment with Actilyse and thrombectomy and 2 patients underwent retransplantation (at POD 10 and 46).

The clinical expression depends on the timing of the onset of HAT as well as on the existence of collat- erals. The natural history of early HAT is biliary tract necrosis followed by uncontrolled sepsis in the immunosuppressed population and even death. Late HAT can be asymptomatic, but in most cases the clinical expressions are biliary tract complications such as necrosis and abscess, as well as liver graft ischemia. The key point in vascular complications is early diagnosis, which allows immediate treatment to avoid graft loss. Doppler ultrasonography is the gold standard for screening protocols, because it detects the absence of hepatic artery flow, even in its intrahepatic branches. The screening protocols or early HAT between different centers are highly variable with respect to frequency. In cases of an early suspicion of HAT, diagnostic plus therapeutic arteriography should be performed ${ }^{11}$.

The clinical features depend on the type of complications (thrombosis, stenosis, pseudoaneurysm), timing of occurrence (early or late presentation after liver transplantation), and promptness of the diagnosis. Treatment options include surgical revascularization, percutaneous thrombolysis, percutaneous angioplasty or retransplantation ${ }^{11}$.

Artery complications represent one of the main causes of graft failure and death after liver transplantation. In addition to parenchymal damage, decreased hepatic artery perfusion can lead to biliary complications such as necrosis, the formation of bilomas, bile leaks, and the development of non-anastomotic strictures. Sonographic demonstration of these findings or of parenchymal abscesses should raise the suspicion of ischemia. A strict surveillance program with doppler ultrasonography can allow early detection of artery complications and prompt therapy. The most common causes of thrombosis are the vessel folding in on itself because of excessive length, organ rejection, elderly donors, slow flow, stenosis, artery reconstruction, and previous liver transplantation. Most stenoses originate at or within a few centimeters of the arterial anastomosis. Several surgical causes in the development of the hepatic artery stenoses have been proposed, such as trauma to the hepatic artery (clamp injury and/or intimal dissection), hepatic artery kinking, differences in vessel caliber requiring oblique anastomoses, and extrinsic compression. Other causes include microvascular preservation injury, disruption of the vasa vasorum of the allograft hepatic artery, and acute cellular rejection ${ }^{11}$.

The key point in vascular complications is early diagnosis, which allows treatment to avoid graft loss. 
Doppler ultrasonography is the gold standard for screening protocols. The use of US color Doppler examination allows the early diagnosis of hepatic arterial complications after liver transplantation. Tardus-parvus waveforms indicated severe impairment of hepatic arterial perfusion from either thrombosis or severe stenosis. The presence of these indirect signs enhanced the accuracy of color Doppler diagnosis, and detection should prompt therapy ${ }^{11}$.

In many instances, HAT occurs soon after surgery for technical reasons, but HAT can also occur several months after transplantation due to factors such as graft rejection or sepsis. Z. Stewart et al showed that donor age is associated with late graft loss induced by HAT ${ }^{13}$. As described by J.Bekker et al, the overall 1-year graft survival rate after liver transplantation for early HAT is approximately $50 \%$, while other vascular complications have graft survival rates up to $86 \%{ }^{12}$.

The incidence of hepatic arterial occlusion ranges from $4 \%$ to $9 \%$ requiring a second liver transplant in over $50 \%$ of patients. Christian E. Oberkofler et al. found that primary arterial patency after LT is predominantly determined by the type of vascular reconstruction rather than patient or disease characteristics 14,15 .

The ideal arterial reconstruction is often described as a short and non-redundant anastomosis fashioned between the recipient and donor hepatic arteries. A.Herrero et al. found in multivariate analysis that the use of a long graft artery, whatever the recipient anastomosis site, was an independent risk factor of early HAT (OR 3.2; 95\% CI 1.2-9; p = 0.02). Arterial reconstruction using a long graft artery on distal recipient arterial site (PHA or CHA/GDA bifurcation) was associated with an increased rate of early HAT compared with reconstruction on other sites $(p=0.02)$. No difference was found between recipient sites of implantation when using a short graft artery ${ }^{16}$.
The favourable outcome of LHAT compared to early arterial thrombosis is allowed by the development of arterial collaterals, that can arise from superior mesenteric artery, splenic artery, inferior phrenic artery, left gastric artery and arteries from the omentum, providing arterial blood supply via the hilar plate. This could explain the persistence of resistive index in patients with no more patent hepatic artery ${ }^{17}$.

Marudanayagam R. et al. concluded that the most common indication for retransplantation was hepatic artery thrombosis (31.6\%). Nearly two-thirds of the retransplantations were performed within 6 months of the primary transplantation. The 1-, 3-, 5- and 10-year patient survival rates following first retransplantation were $66 \%, 61 \%, 57 \%$ and $47 \%$, respectively. Donor age of $<55$ years and a MELD score of $<23$ were associated with better outcome following retransplantation (being independent risk factors predicting outcome following regrafts). Univariate analysis was performed initially to identify factors predicting survival. Early retransplantation was associated with worse outcome compared with late retransplantation $(\mathrm{p}=0.015)^{18}$.

The timing of retransplantation has been shown to play a significant role in both patient and graft survival. Chen et al. demonstrated that patients in whom the interval to retransplantation was 8-30 days displayed lower survival rates compared with those who underwent later retransplantations ${ }^{18}$.

Compliance with ethics requirements: The authors declare no conflict of interest regarding this article. The authors declare that all the procedures and experiments of this study respect the ethical standards in the Helsinki Declaration of 1975, as revised in 2008(5), as well as the national law. Informed consent was obtained from all the patients included in the study. 


\section{References}

1. López-Andújar R, Moya A, Montalvá E, Berenguer M, de Juan M, San Juan F, et al. Lessons learned from anatomic variants of the hepatic artery in 1,081 transplanted livers. Liver Transplantation. 2007 Oct;13(10):1401-4.

2. Oh CK, Pelletier SJ, Sawyer RG, Dacus AR, McCullough CS, Pruett $T L$, et al. Uni- and multi-variate analysis of risk factors for early and late hepatic artery thrombosis after liver transplantation. Transplantation. 2001;71(6):767-72.

3. Piardi T, Lhuaire M, Bruno O, Memeo R, Pessaux P, Kianmanesh $R$, et al. Vascular complications following liver transplantation: $A$ literature review of advances in 2015. World Journal of Hepatology. 2016;8(1):36-57.

4. Gruttadauria S, Foglieni CS, Doria C, Luca A, Lauro A, Marino IR. The hepatic artery in liver transplantation and surgery Vascular anomalies in 701 cases. Clinical Transplantation. 2001;15(5):359-63.

5. Kluger MD, Memeo R, Laurent A, Tayar C, Cherqui D. Survey of adult liver transplantation techniques (SALT): An international study of current practices in deceased donor liver transplantation. Hpb [Internet]. 2011;13(10):692-8. Available from: http:// dx.doi.org/10.1111/j.1477-2574.2011.00348.x

6. Zhong J, Smith C, Walker P, Sheridan M, Guthrie A, Albazaz R. Imaging post liver transplantation part I: vascular complications. Clinical Radiology. W.B. Saunders Ltd; 2020.

7. Vasconcelos-Filho JOM, Magalhães PRM, Monteiro BR, Moura AA, Silva GC, Fonseca-Neto OCL, et al. Frequency of Anatomic Variations on Hepatic Arteries and Types of Reconstruction Employed: Study on Livers Prepared for Transplantation. Transplantation Proceedings. 2020 Jun 1;52(5):1312-3.

8. Warner P, Fusai G, Glantzounis GK, Sabin CA, Rolando N, Patch D, et al. Risk factors associated with early hepatic artery thrombosis after orthotopic liver transplantation - Univariable and multivariable analysis. Transplant International. 2011 Apr;24(4):401-8.

9. Chen J, Weinstein J, Black S, Spain J, Brady PS, Dowell JD. Surgical and endovascular treatment of hepatic arterial complications following liver transplant. Vol. 28, Clinical Transplantation. Blackwell Publishing Ltd; 2014. p. 1305-12.
10. Pareja E, Cortes M, Navarro R, Sanjuan F, López R, Mir J. Vascular complications after orthotopic liver transplantation: Hepatic artery thrombosis. Transplantation Proceedings. 2010 Oct;42(8):2970-2.

11. Frongillo F, Lirosi MC, Nure E, Inchingolo R, Bianco G, Silvestrini $\mathrm{N}$, et al. Diagnosis and Management of Hepatic Artery Complications after Liver Transplantation. Transplantation Proceedings [Internet]. 2015;47(7):2150-5. Available from: http://dx.doi. org/10.1016/j.transproceed.2014.11.068

12. Bekker J, Ploem S, de Jong KP. Early hepatic artery thrombosis after liver transplantation: A systematic review of the incidence, outcome and risk factors. American Journal of Transplantation. 2009 Apr;9(4):746-57.

13. Hutchinson E. Hepatic artery thrombosis. Vol. 7, Nature Reviews Gastroenterology and Hepatology. 2010. p. 69.

14. Mourad MM, Liossis C, Gunson BK, Mergental H, Isaac J, Muiesan $\mathrm{P}$, et al. Etiology and management of hepatic artery thrombosis after adult liver transplantation. Liver Transplantation. 2014;20(6):713-23.

15. Oberkofler CE, Reese T, Raptis DA, Kuemmerli C, de Rougemont $\mathrm{O}$, de Oliveira $\mathrm{ML}$, et al. Hepatic artery occlusion in liver transplantation: What counts more, the type of reconstruction or the severity of the recipient's disease? Liver Transplantation. 2018;24(6):790-802.

16. Herrero A, Souche R, Joly E, Boisset G, Habibeh H, Bouyabrine $\mathrm{H}$, et al. Early Hepatic Artery Thrombosis After Liver Transplantation: What is the Impact of the Arterial Reconstruction Type? World Journal of Surgery. 2017;41(8):2101-10.

17. Capelli R, Allard MA, Ciacio O, Pittau G, Golse N, Vibert E, et al. Late hepatic artery thrombosis after liver transplantation: which strategy? A single-center retrospective study. Transplant International. 2019;32(5):473-80.

18. Marudanayagam R, Shanmugam V, Sandhu B, Gunson BK, Mirza DF, Mayer D, et al. Liver retransplantation in adults: A single-centre, 25-year experience. HPB. 2010;12(3):217-24. 